\title{
Implementation of MOORA Method for Determining Prospective Smart Indonesia Program Funds Recipients
}

\author{
Zaitun, Mustakim, Insanul Kamila, Siti Syahidatul Helma
}

\begin{abstract}
Presidential Instruction No. 7 of 2014 mandates PIP to the Ministry of Education and Culture to summarize Indonesia Smart Card (KIP) and spread PIP funds to students that cannot afford to pay education. However, Indonesia Corruption Watch (2018) explained that the data used for the Smart Indonesia Program (PIP) was still inaccurate because almost half of the poor people with a percentage of $42.9 \%$ were not registered as participants in the Smart Indonesia Program (PIP). According to ICW, this is due to the data used for the process of determining the candidates for the Smart Indonesia Program recipients of the funds are still inaccurate and harming others who supposed to get funds. One method that usually used as a decision-making technique in the research is the Multi-Objective Optimization Ratio Analysis (MOORA) method which is a multi-criteria decision-making that has five main steps as a technique and it can be used to rank prospective PIP fund recipients based on the highest to the lowest preference values. The results of this study indicate that the first rank with the highest value was 0.0539 and the last rank with the lowest value was 0.0211 so it used to ease the stakeholders to determine the amount of KIP recipients based on the preference values. This method can be applied for stakeholders needed in compared to monotonous data processing using estimates.
\end{abstract}

Index Terms: Smart Indonesia Program, Indonesia Smart Card, Education, Multi-Objective Optimization Ratio Analysis, Criteria Weights, Preference values.

\section{INTRODUCTION}

Poverty and Education are two aspects related to human welfares. Poverty is one of the factors that causing limitation in obtaining education, whereas education aims to improve the human welfares [1]. The low quality of education in Indonesia is influenced by some factors, one of them is the high cost of education which causes the middle and lower classes were unable to continue their education and getting to drop out of the school [2]. Based on data from the National Socio-Economic Survey in 2017, the percentage of dropout

Revised Manuscript Received on December 30, 2019.

* Correspondence Author

Zaitun, Faculty of Education and Teaching, Universitas Islam Negeri Sultan Syarif Kasim Riau, Pekanbaru, Indonesia.

Mustakim, Department of Information System, Faculty of Science and Technology, Universitas Islam Negeri Sultan Syarif Kasim Riau, Pekanbaru, Indonesia.

Insanul Kamila, Department of Information System, Faculty of Science and Technology, Universitas Islam Negeri Sultan Syarif Kasim Riau, Pekanbaru, Indonesia.

Siti Syahidatul Helma, Department of Information System, Faculty of Science and Technology, Universitas Islam Negeri Sultan Syarif Kasim Riau, Pekanbaru, Indonesia.

(C) The Authors. Published by Blue Eyes Intelligence Engineering and Sciences Publication (BEIESP). This is an open access article under the CC BY-NC-ND license (http://creativecommons.org/licenses/by-nc-nd/4.0/)

rates for Primary Schools (SD) was 0.32\%, Junior High Schools (SMP) was $1.54 \%$ and Senior High Schools (SMA) was $4.74 \%$. From these data, it concluded that the higher education level means the higher dropout rate. Even there are already free school programs in several region, but the dropout rate is quite high [15]. This is oppositely contradicted to the opening of the 1945 Constitution which explains that the purpose of the state was to advance the general welfare and to educate the nation's life. According to UNESCO (2015), education in Indonesia was ranked 10th from 14 developing countries. Meanwhile, according to the PISA research (The Program for International Student Assessment) initiated by countries that are members of the OECD (Organization for Economic Cooperation and Development), Indonesia was ranked 64th from all PISA participating countries. The PISA is a study that believed to be a great legitimacy in describing the quality of education in a country [3]. The ways is taken by the Indonesian government in improving the quality of education is to assist middle and lower classes in obtaining education through the Smart Indonesia Program (PIP). PIP is a program managed by the Ministry of Education and Culture that aims to help people aged 6 to 21 years in gaining access to education and getting education services to graduate secondary education units, to prevent the students get dropouts from the school. PIP funds is used to finance school fees, buy books, uniforms, stationery, transportation, pocket money, and other costs that can support the education of students. The process of determining prospective PIP fund recipients starts from the proposed of education unit in each schools by marking the eligibility status of students as prospective PIP fund recipients to the Dapodik application or to the district / city education office or the provincial education office [9] However, a survey from Indonesia Corruption Watch (2018) explained that the data used for the Smart Indonesia Program (PIP) was still inaccurate because almost half of poor people with a percentage of $42.9 \%$ were not registered as participants in the Smart Indonesia Program (PIP). According to ICW, this is due to the data used for the process of determining the candidates for the Smart Indonesia Program recipients of the funds are still inaccurate According to research conducted at SMAN 1 Sembawa in 2019 it was concluded that the implementation of the PIP was still not working as it should, it was caused by the students in receiving PIP funds that were not on target because the data used in determining the prospective PIP recipients was still less accurate and harming others who supposed to get funds [4][14]. 


\section{Implementation of MOORA Method for Determining Prospective Smart Indonesia Program Funds Recipients}

A decision-making technique is needed in determining the students are eligible as recipients of the Smart Indonesia Program funds to prevent the problems. In general, decision making can be defined as recognizing and choosing an alternative from a set of alternatives based on the preferences values of the decision-makers [16]. One method that is used usually in research as a decision making technique is the Multi-Objective Optimization Ratio Analysis (MOORA) Method [5]. The MOORA method was introduced by Brauers in 2004 [5]. This method is multi-criteria techniques which has five main steps: determining goals and identifying attributes or criteria, displaying all alternatives in the form using decision matrix, then normalizing the decision matrix and multiplying the matrix with each weight of criteria to produce a weighted normalization matrix, after that determine the value of preferences in each alternative by adding up all the criteria in benefit (beneficial attributes) and reduce them to the criteria that are non beneficial (non-beneficial attributes), and make a sequence or ranking based on the value of the highest preference to the lowest. The conclusion was the best alternative has the highest preference value while the worst alternative has a low preference value [5] [6].

A research conducted by Hanifatulqolbi D, et al (2019) was determined the teacher who had the best performance in one of the Islamic boarding school institutions by designing a decision support system using the MOORA method. In this study used 2 main criteria, that was hard competency and soft competency that having supported in competency. Based on these studies it was concluded that the MOORA method can help in determining the teacher who has the best performance quickly and more objectively [6]. Other research using the MOORA method is to provide recommendations regarding students who are eligible to receive scholarships at the AMIK Tunas Bangsa foundation (Andani SR, et al, 2019) [7] and was also used to evaluate the performance of 4 machines in an industry consisting of 6 criteria (Domínguez L Perez, et al, 2018) [8].

In this study will be used MOORA method to provide recommendations for eligible students as prospective recipients of the Smart Indonesia Program funds by sorting all students based on existed criteria. This result are expected to be able used as a parameters and recommendations for relevant parties and stakeholders, especially the Education Authorities, Agencies/Schools in determining the eligibility of students receiving PIP Funds for implementation of the PIP which is also a national policy as the its Implementation Guidelines (PIP operational guidelines) and targeted exactly to the lower middle class people who are properly felt the benefits of the program.

\section{METHOD}

The research methodology is a reference research for explained the stage in completing this study which is divided into several main stages, study literature, data collection, implementation of MOORA method, and performing the evaluation of this study. Literature review was done by reading and study theories to get preferences such as journals, scientific publications, books and materials in completing this research. Data collection used in the Senior High Schools (Pekanbaru) 10 in the academic year 2019/2020. 882 alternatives were used 8 criteria, that is Indonesian Smart Card Recipient Status (KIP), Social Protection Card
Recipient Status (KPS), Student Living Type (JT), Transportation used (AT), Father's Occupation (PKA), Mother's Occupation (PKI), Father's Income (PHA), and Mother's Income (PHI) of students. In Implementation of MOORA method, data collection was getting into numerical numbers or transformation arranged sequentially and determining the attributes type and each values of criteria weights then proceed into MOORA calculations. The last stage was evaluation to determine the conclusion of the research. The stage methodology can be seen in the following Figure 1:

\section{A. Smart Indonesia Program (PIP)}

Presidential Instruction No. 7 of 2014 mandates PIP to the Ministry of Education and Culture to summarize Smart Indonesia Card (KIP) and spread PIP funds to students that cannot afford to pay education [11]. Smart Indonesia Program is managed by the Ministry of Education and Culture in accordance to its duties and obligations to ensure students getting their level of education until graduating from secondary education and to prevent the students get dropouts from the school, receiving education services especially for children aged 6 to 21 years [9].

\section{B. MOORA}

MOORA is an objective multi-criteria method used to solve various problems related to decision making [10]. MOORA method also known as multi-attribute optimization is the process of concomitantly two or more attributes subject to certain limitations [12]. The MOORA method has a simple mathematical calculations and is easily understood systematically [8]. The steps in the MOORA method are:

1. Determine the objectives and identify alternatives and criteria to be used, in this case using 882 alternatives and 8 criteria as previously described.

2. Making a decision matrix [10], as below :

$$
\mathrm{X}=\begin{array}{ccc}
x_{11} & x_{12} & x_{1 i} \\
: & : & : \\
x_{j 1} & x_{j 2} & x_{i j}
\end{array}
$$

Explanation :

$\mathrm{X}=$ Decision matrix

$\mathrm{X}_{\mathrm{ij}}=\mathrm{m}$ alterntive values in $\mathrm{n}$ criterion

3. Normalization matrix [6]

$$
\mathrm{X}^{*}=\frac{x i j}{\sqrt{\left[\sum_{j=1}^{m} x_{i j}^{2}\right]}}
$$

Where $x i j$ is a $\mathrm{j}$ alternative matrix in $\mathrm{i}$ criterion, while $\mathrm{i}$ which is values $1,2,3$ to $\mathrm{n}$ is the order number of criteria and $\mathrm{j}$ which is values $1,2,3, \ldots, \mathrm{m}$ is an alternative sequence number and $\mathrm{X} * \mathrm{ij}$ is a $\mathrm{j}$ alternative normalization matrix in i criterion.

4. Calculating preferences value [6][8]

Before determining the preference value, do a multiplication of each value in the normalization matrix with the weight of each criterion.

$$
\mathrm{X}^{*}{ }_{i j w}=\sum_{j=1}^{g} W_{j} X_{i j}^{*}
$$

Then calculate the optimization value by adding up the maximum value type (beneficial attributes) for each alternative and subtracting it from the minimum value type (non-beneficial attributes) for each alternative on the all alternative belong to the interval $(0 ; 1)$ [6][13] with the following formula [13]: 


$$
\mathrm{Y}^{*_{\mathrm{j}}}=\sum_{i=1}^{i=g} X_{i j w}^{*}-\sum_{i=g+1}^{i=n} X_{i j w}^{*}
$$

5. Ranking

The ranking is done by sorting the preference value, which the alternative having the highest preference value is considered the best alternative while the lowest preference value is considered as the worst alternative [6] [8].

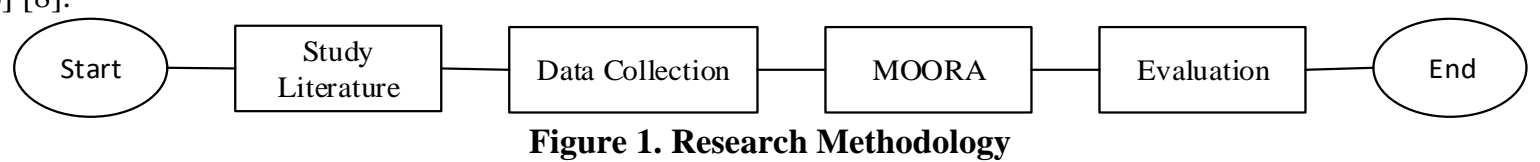

\section{RESULT AND ANALYSIS}

Identificating problems aims to make decisions more directed and not deviated to reach the goal. This calculation aims to determine the ranking based the criteria for prospective Smart Indonesian Card recipients at SMA N 10 Pekanbaru using the MOORA method. The following table 1 is the initial data from SMA N 10 Pekanbaru that will be used in determining rank.

Table 1. Initial Data of KIP Recipient Candidates

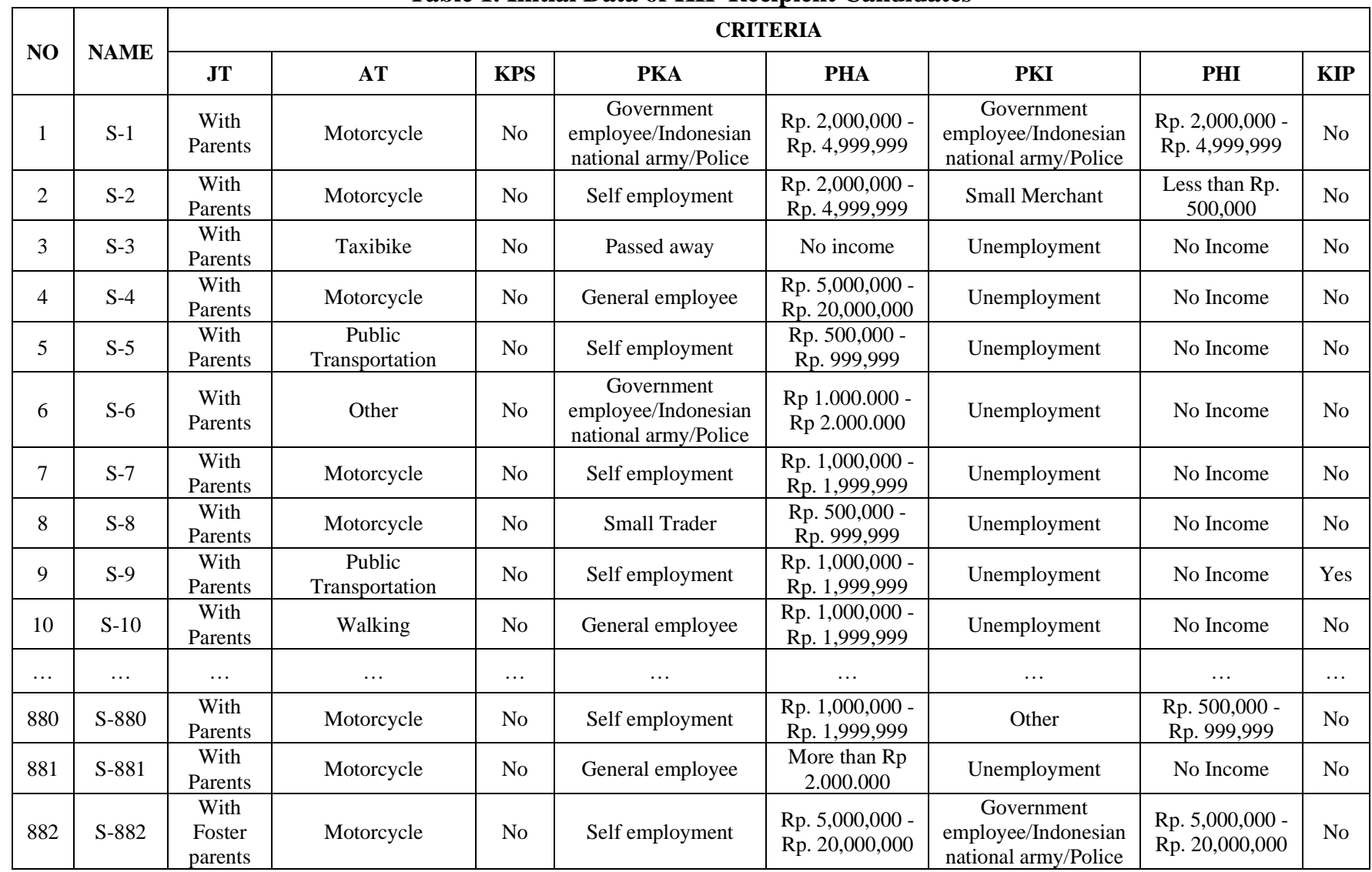

The following table 2 shows the criteria weights using the MOORA technique. The weight / transformation table shows the changes in numerical numbers arranged in sequence with the type of beneficial attributes data because each criteria has an important role. In criteria weights given a random value according to the ranking needs of the highest criteria to the lowest which if the entire amount of weight added criteria will produce a value equal to 1 (one). In Smart Card Recipient Status (KIP), Social Protection Card Recipient Status (KPS) were the dominant criteria so they get the higher scores than others. Following is the description of each weighting and KIP prospective recipient criteria in table 2:

Table 2. Weights and Criteria on MOORA

\begin{tabular}{|c|c|c|c|c|c|}
\hline No & Criteria & Sub Criteria & $\begin{array}{c}\text { Weight / } \\
\text { Transformation }\end{array}$ & Type & $\begin{array}{l}\text { Criteria } \\
\text { Weights }\end{array}$ \\
\hline 1 & KIP & Yes & 2 & \multirow{2}{*}{$\begin{array}{c}\text { Beneficial } \\
\text { attributes }\end{array}$} & \multirow[t]{2}{*}{0.2} \\
\hline & & No & 1 & & \\
\hline 2 & KPS & Yes & 2 & \multirow{2}{*}{$\begin{array}{c}\text { Beneficial } \\
\text { attributes }\end{array}$} & \multirow[t]{2}{*}{0.2} \\
\hline & & No & 1 & & \\
\hline 3 & $\mathrm{AT}$ & Walking & 9 & Beneficial & 0.1 \\
\hline
\end{tabular}


International Journal of Engineering and Advanced Technology (IJEAT) ISSN: 2249 - 8958, Volume-9 Issue-2, December, 2019

\begin{tabular}{|c|c|c|c|c|c|}
\hline No & Criteria & Sub Criteria & $\begin{array}{c}\text { Weight / } \\
\text { Transformation }\end{array}$ & Type & $\begin{array}{l}\text { Criteria } \\
\text { Weights }\end{array}$ \\
\hline & & Public Transportation & 8 & \multirow[t]{8}{*}{ attributes } & \\
\hline & & Taxibike & 7 & & \\
\hline & & Train & 6 & & \\
\hline & & Shuttle & 5 & & \\
\hline & & Private vehicle & 4 & & \\
\hline & & Motorcycle & 3 & & \\
\hline & & Car & 2 & & \\
\hline & & Other & 1 & & \\
\hline \multirow[t]{10}{*}{4} & \multirow[t]{10}{*}{ PHA } & No Income & 10 & \multirow{10}{*}{$\begin{array}{c}\text { Beneficial } \\
\text { attributes }\end{array}$} & \multirow[t]{10}{*}{0.1} \\
\hline & & Less than Rp. 500,000 & 9 & & \\
\hline & & Rp. 500,000 - Rp. 999,999 & 8 & & \\
\hline & & Les than Rp 1.000 .000 & 7 & & \\
\hline & & Rp. 1,000,000 - Rp. 1,999,999 & 6 & & \\
\hline & & Rp 1.000.000 - Rp 2.000.000 & 5 & & \\
\hline & & More than Rp 2.000 .000 & 4 & & \\
\hline & & Rp. 2,000,000 - Rp. 4,999,999 & 3 & & \\
\hline & & Rp. 5,000,000 - Rp. $20,000,000$ & 2 & & \\
\hline & & More than Rp. 20,000,000 & 1 & & \\
\hline \multirow[t]{10}{*}{5} & \multirow[t]{10}{*}{ PHI } & No Income & 10 & \multirow{10}{*}{$\begin{array}{c}\text { Beneficial } \\
\text { attributes }\end{array}$} & \multirow[t]{10}{*}{0.1} \\
\hline & & Less than Rp. 500,000 & 9 & & \\
\hline & & Rp. 500,000 - Rp. 999,999 & 8 & & \\
\hline & & Less than Rp 1.000 .000 & 7 & & \\
\hline & & Rp. 1,000,000 - Rp. 1,999,999 & 6 & & \\
\hline & & Rp 1.000.000 - Rp 2.000.000 & 5 & & \\
\hline & & More than Rp 2.000 .000 & 4 & & \\
\hline & & Rp. 2,000,000 - Rp. 4,999,999 & 3 & & \\
\hline & & Rp. 5,000,000 - Rp. 20,000,000 & 2 & & \\
\hline & & More than Rp. 20,000,000 & 1 & & \\
\hline \multirow[t]{5}{*}{6} & \multirow[t]{5}{*}{$\mathrm{JT}$} & Hostel & 5 & \multirow{5}{*}{$\begin{array}{c}\text { Beneficial } \\
\text { attributes }\end{array}$} & \multirow[t]{5}{*}{0.1} \\
\hline & & Boarding House & 4 & & \\
\hline & & With Foster Parents & 3 & & \\
\hline & & With Parents & 2 & & \\
\hline & & Other & 1 & & \\
\hline \multirow[t]{13}{*}{7} & \multirow[t]{13}{*}{ PKA } & Passed Away & 13 & \multirow{13}{*}{$\begin{array}{c}\text { Beneficial } \\
\text { attributes }\end{array}$} & \multirow[t]{13}{*}{0.1} \\
\hline & & Unemployment & 12 & & \\
\hline & & Labor & 11 & & \\
\hline & & Farmer & 10 & & \\
\hline & & Breeder & 9 & & \\
\hline & & Pension & 8 & & \\
\hline & & Small Merchant & 7 & & \\
\hline & & Big Merchant & 6 & & \\
\hline & & Self employment & 5 & & \\
\hline & & Entrepreneur & 4 & & \\
\hline & & General employee & 3 & & \\
\hline & & $\begin{array}{c}\text { Government employee/Indonesian } \\
\text { national army/Police }\end{array}$ & 2 & & \\
\hline & & Other & 1 & & \\
\hline 8 & PKI & Passed away & 12 & Beneficial & 0.1 \\
\hline & & Unemployment & 11 & attributes & \\
\hline & & Labor & 10 & & \\
\hline & & Farmer & 9 & & \\
\hline & & Breeder & 8 & & \\
\hline & & Pension & 7 & & \\
\hline & & Small merchant & 6 & & \\
\hline & & Self employment & 5 & & \\
\hline & & Entrepreneur & 4 & & \\
\hline & & General employee & 3 & & \\
\hline & & $\begin{array}{c}\text { Government employee/Indonesian } \\
\text { national army/Police }\end{array}$ & 2 & & \\
\hline & & Other & 1 & & \\
\hline
\end{tabular}

Data transformation shown the weighting scores in MOORA. Based on the data in table 2 above, the resulting transformation of alternative data from 882 KIP recipient candidates is as shown in Table 3: 
Implementation of MOORA Method for Determining Prospective Smart Indonesia Program Funds Recipients

Table 3. Data Transformation

\begin{tabular}{|c|c|c|c|c|c|c|c|c|c|}
\hline \multirow{2}{*}{ NO } & \multirow{2}{*}{ NAME } & \multicolumn{8}{|c|}{ CRITERIA } \\
\cline { 3 - 10 } & & JT & AT & KPS & PKA & PHA & PKI & PHI & KIP \\
\hline 1 & S-1 & 2 & 3 & 1 & 2 & 3 & 2 & 3 & 1 \\
\hline 2 & S-2 & 2 & 3 & 1 & 5 & 3 & 6 & 9 & 1 \\
\hline 3 & S-3 & 2 & 7 & 1 & 13 & 10 & 11 & 10 & 1 \\
\hline 4 & S-4 & 2 & 3 & 1 & 3 & 2 & 11 & 10 & 1 \\
\hline 5 & S-5 & 2 & 8 & 1 & 5 & 8 & 11 & 10 & 1 \\
\hline$\ldots$ & $\ldots$ & $\ldots$ & $\ldots$ & $\ldots$ & $\ldots$ & $\ldots$ & $\ldots$ & $\ldots$ & $\ldots$ \\
\hline$\ldots$ & $\ldots$ & $\ldots$ & $\ldots$ & $\ldots$ & $\ldots$ & $\ldots$ & $\ldots$ & $\ldots$ & $\ldots$ \\
\hline 881 & S-881 & 2 & 3 & 1 & 3 & 4 & 11 & 10 & 1 \\
\hline 882 & S-882 & 3 & 3 & 1 & 5 & 2 & 2 & 2 & 1 \\
\hline
\end{tabular}

In the next stage, making a decision matrix based on transformed data. Matrices are made according to a lot of data arranged to the rules of the matrix. The following table is a decision matrix of the data:

\begin{tabular}{|c|c|c|c|c|c|}
\hline 2 & 3 & 1 & 2 & 3 & 2 \\
\hline 2 & 3 & 1 & 5 & 3 & 6 \\
\hline 2 & 7 & 1 & 13 & 10 & 11 \\
\hline 2 & 3 & 1 & 3 & 2 & 11 \\
\hline 2 & 8 & 1 & 5 & 8 & 11 \\
\hline$\cdots$ & $\cdots$ & $\ldots$ & $\cdots$ & $\ldots$ & $\ldots$ \\
\hline$\ldots$ & $\ldots$ & $\ldots$ & $\ldots$ & $\ldots$ & $\ldots$ \\
\hline 2 & 3 & 1 & 3 & 4 & 11 \\
\hline 3 & 3 & 1 & 5 & 2 & 2 \\
\hline
\end{tabular}

Normalization aims to merge each matrix element so its have a similar value. Normalization was done by dividing the value of a data with the root of the sum of the squares of data in one criterion.

The first step is determining the value of $\sqrt{ }[\Sigma X i j 2]$ for each criterion. For example, the first criteria, Student Living Type (AT), absolute results are obtained as in equation 1 results below:

$$
\begin{aligned}
& \sqrt{ }\left[\Sigma \mathrm{X}_{i j}{ }^{2}\right]= \sqrt{\sum 2^{2}+2^{2}+2^{2}+2^{2}+2^{2}+2^{2}+2^{2}+2^{2}+} \\
& 2^{2}+2^{2}+2^{2}+2^{2}+3^{2}+\cdots+\cdots+2^{2}+ \\
& 3^{2} \\
&=\mathbf{6 1 . 1 0 6 4 6}
\end{aligned}
$$

Use the same method to get the value $\sqrt{ }[\Sigma X i j 2]$ on others criteria. So we get the value $\sqrt{ }[\Sigma \mathrm{X} i j 2]$ for each criteria as follows:

Table 4 values of $\sqrt{ }\left[\Sigma X_{i j}{ }^{2}\right]$ for each criteria

\begin{tabular}{|c|c|c|c|c|c|c|c|c|}
\hline CRITERIA & JT & AT & KPS & PKA & PHA & PKI & PHI & KIP \\
\hline$\sqrt{[}\left[\mathrm{X}_{i j}{ }^{2}\right]$ & 61.10 & 148.57 & 31.84 & 173.67 & 146.35 & 276 & 258.41 & 32.31 \\
\hline
\end{tabular}

After that, do the normalization by dividing the value of each alternative based on each criterion as showed by table 4 . For example in the first alternative data S-1 for the criteria AT, normalization was done by dividing the value of S-1's AT that is 2 with a value of 61.10 equal to 0.0327 . Do the same steps for all data so that it produces the normalized decision matrix as follows:

\begin{tabular}{|ccccccc}
\cline { 1 - 3 } 0.0327 & 0.0202 & 0.0314 & 0.0115 & 0.0205 & 0.0072 \\
0.0327 & 0.0202 & 0.0314 & 0.0288 & 0.0205 & 0.0217 \\
0.0327 & 0.0471 & 0.0314 & 0.0749 & 0.0683 & 0.0399 \\
0.0327 & 0.0202 & 0.0314 & 0.0173 & 0.0137 & 0.0399 \\
0.0327 & 0.0538 & 0.0314 & 0.0288 & 0.0547 & 0.0399 \\
$\ldots$ & $\ldots$ & $\ldots$ & $\ldots$ & $\ldots$ & $\ldots$ \\
$\ldots$ & $\ldots$ & $\ldots$ & $\ldots$ & $\ldots$ & $\ldots$ \\
0.0327 & 0.0202 & 0.0314 & 0.0173 & 0.0273 & 0.0399 \\
0.0491 & 0.0202 & 0.0314 & 0.0288 & 0.0137 & 0.0072 \\
\hline
\end{tabular}

After normalizing, multiply each data by the weight of each criterion. For example in the first alternative data S1 on criteria AT has a value of 0.327 multiplied by the weight of AT was 0.1 then the result is 0.0033 . Do the same thing for each data on each criterion, so that the following results are obtained:

\begin{tabular}{|cllllll|}
\cline { 1 - 3 } 0.0033 & 0.0020 & 0.0063 & 0.0012 & 0.0020 & 0.0007 \\
0.0033 & 0.0020 & 0.0063 & 0.0029 & 0.0020 & 0.0022 \\
0.0033 & 0.0047 & 0.0063 & 0.0075 & 0.0068 & 0.0040 \\
0.0033 & 0.0020 & 0.0063 & 0.0017 & 0.0014 & 0.0040 \\
0.0033 & 0.0054 & 0.0063 & 0.0029 & 0.0055 & 0.0040 \\
$\ldots$ & $\ldots$ & $\ldots$ & $\ldots$ & $\ldots$ & $\ldots$ \\
$\ldots$ & $\ldots$ & $\ldots$ & $\ldots$ & $\ldots$ & $\ldots$ \\
0.0033 & 0.0020 & 0.0063 & 0.0017 & 0.0027 & 0.0040 \\
0.0049 & 0.0020 & 0.0063 & 0.0029 & 0.0014 & 0.0007 \\
\hline
\end{tabular}

Normalized measurements are added in the case of maximization (for beneficial attributes) and reduced in minimization (for non-beneficial attributes) or reducing the maximum and minimum values in each row to get rankings for each row according to table 2 .

In this case, all the attributes are beneficial so there is no non beneficial attributes. For example, to calculate the optimization value in the first data, add up all the values in the beneficial attributes criteria then subtract them with the non-beneficial attributes. But, all of the criteria are beneficial, adding up the whole number as follows:

$\mathrm{Y} 1=\mathrm{C} 1+\mathrm{C} 2+\mathrm{C} 3+\mathrm{C} 4+\mathrm{C} 5+\mathrm{C} 6+\mathrm{C} 7+\mathrm{C} 8=0.0033+$ $0.0020+0.0063+0.0012+0.0020+0.0007=0.228$.

Do the same for other alternatives so that the following results are obtained: 
Table 5. Optimization Values for Each Alternative

\begin{tabular}{|c|c|c|c|}
\hline Alternative & $\begin{array}{c}\text { Max/ Benefit } \\
(\mathbf{C 1}+\mathbf{C 2}+\mathbf{C 3}+\mathbf{C} \ldots++\mathbf{C} 8)\end{array}$ & $\begin{array}{c}\text { Min / } \\
\text { Cost (0) }\end{array}$ & $\begin{array}{c}\text { Yi } \mathbf{i} \text { (Max- } \\
\text { Min) }\end{array}$ \\
\hline S-1 & 0.0228 & 0 & 0.0228 \\
\hline S-2 & 0.0283 & 0 & 0.0283 \\
\hline S-3 & 0.0426 & 0 & 0.0426 \\
\hline S-4 & 0.0287 & 0 & 0.0287 \\
\hline S-5 & 0.0373 & 0 & 0.0373 \\
\hline$\ldots$ & $\ldots$ & $\ldots$ & $\ldots$ \\
\hline$\ldots$ & $\ldots$ & $\ldots$ & $\ldots$ \\
\hline S-881 & 0.0301 & 0 & 0.0301 \\
\hline S-882 & 0.0251 & 0 & 0.0251 \\
\hline
\end{tabular}

After each ranking is obtaining used the MOORA method, table 6 below can show the final results of each alternative in the highest to the lowest preferences:

Tabel 6. MOORA Ranking Result

\begin{tabular}{|c|c|c|}
\hline \multirow{2}{*}{ Alternative } & $\mathbf{Y i}$ = (Max- Min) & Ranking \\
\hline S-36 & 0.0539 & 1 \\
\hline S-583 & 0.0539 & 2 \\
\hline S-61 & 0.0534 & 3 \\
\hline S-561 & 0.0532 & 4 \\
\hline S-279 & 0.0526 & 5 \\
\hline$\ldots$ & $\ldots$ & $\ldots$ \\
\hline$\ldots$ & $\ldots$ & $\ldots$ \\
\hline S-237 & 0.0211 & 881 \\
\hline S-758 & 0.0211 & 881 \\
\hline
\end{tabular}

From above, it is shown the difference in the final results of each alternative where the first rank has the highest value is in the alternative S-36 with a value is 0.0539 and the alternative S-758 has the lowest value with a value is 0.0211 . Then this ranking can be applied by several stakeholders such as schools, education authorities, and other stakeholders in determining and selecting potential KIP recipients for school.

\section{CONCLUSION}

Based on the results of this research used the MOORA method it can be concluded that:

1. This method can be applied to determine the ranking of prospective KIP recipient data with the highest preferences as first ranking results in alternative S-36 with a value is 0.0539 and at the last rank in alternative S-758 has the lowest value with a value is 0.0211 , so MOORA method can be used in this case. In addition, stakeholders can determine the amount of KIP recipients that eligible based on the ranking that has been obtained.

2. The results of data processing carried out using the MOORA method gained a final score that is more effective in determining the prospective KIP recipient for the implementation in future cases, compared to monotonous data processing using estimates. For further research, other decision making techniques can be applied.

\section{REFERENCES}

1. Aziz AR. Implementasi Instruksi Presiden ( Inpres ) No 07 Tahun 2014 tentang Kebijakan Kartu Indonesia Pintar ( KIP ) dalam Meningkatkan Mutu Pendidikan Masyarakat Miskin di Indonesia. Jurnal Pemerintahan dan Politik Global. Januari 2019; 4(2): 58-68

2. Indra, Nahdah P. Meningkatkan Mutu Pendidikan di Indonesia Melalui Supervisi Pendidikan. INA-Rxiv, 18 May 2019.

3. Pratiwi I. Pisa Effect On Curriculum In Indonesia. Jurnal Pendidikan dan Kebudayaan. 2019; 4(1):51-71.

4. Hayati N \& Sari EY. Evaluasi Implementasi Program Indonesia Pintar Di Sma Negeri 1 Sembawa. Prosiding Seminar Nasional Pendidikan Program Pascasarjana Universitas Pgri Palembang. 2019. 468-480.Wait

5. Alinezhad A \& Khalili J. New Methods and Applications in Multiple Attribute Decision Making (MADM). Islamic Azad University: Iran. Wait

6. Hanifatulqolbi D, dkk. Decision support system for considering the best teacher performance using MOORA method. 2018 International Conference of Computer and Informatics Engineering (IC2IE). 2018. $1-7$

7. Andani SR, dkk. Application of the MOORA Method for Decision Making in Receiver Foundation Scholarship in AMIK Tunas Bangsa. The International Conference on Computer Science and Applied Mathematic. 2019. 1-6.

8. Domínguez L.P., dkk. Application of the MOORA method for the evaluation of the industrial maintenance system. International Meeting on Applied Sciences and Engineering. 2018. 1-6.

9. Peraturan Direktur Jenderal Pendidikan Dasar dan Menengah tentang Petunjuk Pelaksanaan Program Indonesia Pintar pada Jenjang Pendidikan Dasar dan Menengah. 2018.

10. Karande. P \& CHAKRABORTY. S. Application of multi-objective optimization on the basis of ratio analysis (MOORA) method for materials selection. Materials \& Design. 2012: 37. 317-324.

11. Instruksi Presiden Republik Indonesia Nomor 7 Tahun 2014

12. Chakraborty, S. (2011). Applications of the MOORA method for decision making in manufacturing environment. The Internationa Journal of Advanced Manufacturing Technology, 54(9-12), 1155-1166.

13. Brauers, W. K., \& Zavadskas, E. K. (2009). Robustness of the multi-objective MOORA method with a test for the facilities sector. Technological and economic development of economy, 15(2), 352-375.

14. Wulansari, D. J., Murtiyasa, B., \& Kom, M. (2017). Sistem Pendukung Keputusan Untuk Menentukan Penerima Kartu Indonesia Pintar Menggunakan Metode Simple Additive Weighting (Doctoral dissertation, Universitas Muhammadiyah Surakarta).

15. Mirani, D., \& Agustina, S. (2018, March). Analysis Of The Implementation Of Smart Indonesia Program Through Indonesia Smart Card In Palembang City 2016. In 2018 Annual Conference of Asian Association for Public Administration:" Reinventing Public Administration in a Globalized World: A Non-Western Perspective"(AAPA 2018). Atlantis Press.

16. Rezaei, J. (2016). Best-worst multi-criteria decision-making method: Some properties and a linear model. Omega, 64, 126-130.

\section{AUTHORS PROFILE}

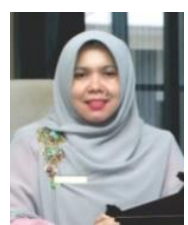

Zaitun, is a lecturer at Faculty of Education and Teaching of Universitas Islam Negeri Sultan Syarif Kasim Riau in Sociology Education subject. She is a Vice Dean of Academic Affairs and Institutional Development Faculty of Science and Technology Universitas Islam Negeri Sultan Syarif Kasim Riau.

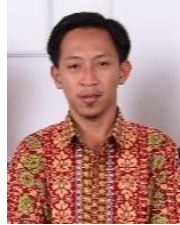

Mustakim, is a lecturer at Departement of Information System Faculty of Science and Technology Universitas Islam Negeri Sultan Syarif Kasim Riau. Subject expert at Data Mining and Big Data. Most of his research and publication are integrated study of Data Mining with Tafsir, Data Mining with Education and Data Mining with Software Engineering. He is a founder of Puzzle Research Data Technology.

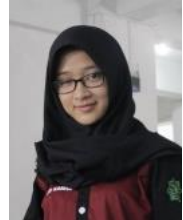

Insanul Kamila, is a student at Information System Department at Universitas Islam Negeri Sultan Syarif Kasim Riau, and a member of Puzzle Research Data Technology.

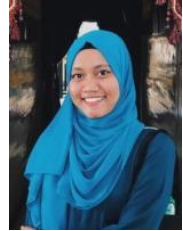

Siti Syahidatul Helma, is a student at Information System Department at Universitas Islam Negeri Sultan Syarif Kasim Riau, and a member of Puzzle Research Data Technology.

Published By:

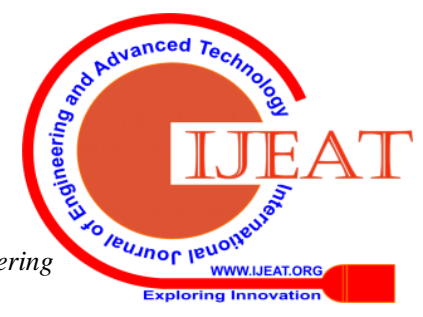

